\title{
Behavioural traits of competent Concholepas concholepas (loco) larvae
}

\author{
Patricio H. Manríquez ${ }^{1,2, *}$, Juan Carlos Castilla ${ }^{3}$
}

\begin{abstract}
${ }^{1}$ Laboratorio Costero de Recursos Acuáticos de Calfuco and ${ }^{2}$ Instituto de Ciencias Marinas y Limnológicas (formerly Instituto de Biología Marina 'Dr. Jürgen Winter'), Universidad Austral de Chile, Casilla 567, Valdivia, Chile

${ }^{3}$ Estación Costeras de Investigaciones Marinas (ECIM, Las Cruces) and Centre for Advanced Studies in Ecology \& Biodiversity, Facultad de Ciencias Biológicas, Pontificia Universidad Católica de Chile, Casilla 114-D, Santiago, Chile
\end{abstract}

\begin{abstract}
Swimming activity of competent Concholepas concholepas (Bruguière, 1789) larvae, under different photoperiod, water turbulence and settlement cues were investigated in laboratory experiments. At night, larvae mainly swam to the water surface and then sank passively to the bottom. During the day, regardless of the photoperiod, larvae mainly stayed on the bottom, occasionally exhibiting upward movements. During the swimming period, larvae displayed the capacity to adhere to floating substrata through several mechanisms, including the secretion of a long and sticky mucous thread, air bubble capture or taking advantage of the water tension. The presence of C. concholepas prey, such as the mussel Semimytilus algosus and the chthamaloid barnacle Notochthamalus scabrosus, significantly influenced the swimming activity of competent $C$. concholepas larvae, inducing them to stay close to the bottom where prey were present. C. concholepas prey also triggered the initiation of larvae crawling, a characteristic of the early benthic life of $C$. concholepas. Although our laboratory experiments are proxies of nature, they are in good agreement with field observations in shallow nearshore areas (< ca. $0.5 \mathrm{~km}$ from shore) that recorded higher abundances of competent $C$. concholepas larvae (which are often associated with floating substrata) captured by surface planktonic tows during the night rather than day. Similarly, competent $C$. concholepas larvae abundances were higher in tows through inner nearshore foam slicks than in non-slick areas. The results suggest that the presence of endogenous swimming behaviour in these larvae may be a key factor enhancing adherence to floating substrata. The laboratory discovery of vertical buoyancy provides new information leading to a better understanding of the distribution and abundance patterns of these larvae in inner nearshore waters.
\end{abstract}

KEY WORDS: Chile · Concholepas concholepas · Larval distribution and transport · Swimming behaviour $\cdot$ Rafting $\cdot$ Mucous thread $\cdot$ Stickiness $\cdot$ Foam slicks

Resale or republication not permitted without written consent of the publisher

\section{INTRODUCTION}

The larvae of numerous marine benthic invertebrates spend long periods in the plankton prior to settlement (Thorson 1950, Bayne 1965, Pechenik 1986, 2000, Young \& Chia 1987, Young 1995), where they must remain suspended, locate and gather food, avoid predators and unfavourable conditions, disperse to new areas, and select sites for settlement (Strathmann 1974, Palmer \& Strathmann 1981, Scheltema 1986). The importance of larval behaviour has been recog- nised as an essential component of marine ecology (Forward 1988, Young 1995), and the role of inner nearshore oceanographic processes influencing larval dispersal and the recruitment of benthic organisms has been the focus of recent research (reviewed by Le Fèvre \& Bourget 1992, Castilla et al. 2002, Largier 2002). The measurement of larval abundances and distribution in the water column are precluded in part by the absence of knowledge concerning the interactions between environmental factors and larval traits. It has been suggested that for most marine invertebrates, this 
is due to the spatio-temporal variability in larval abundance (Gaines \& Bertness 1993) and unknown aspects of larval behaviour (Miron et al. 1995). Although in marine invertebrates larval transport to settlement habitats seems to be controlled mainly by hydrographic factors (Thorson 1950), larval behaviour may also influence their final destination (e.g. Butman 1987, Forward 1988, Pineda 1994, Young 1995).

The loco (Chilean abalone) Concholepas concholepas (Bruguière, 1789) is an economically and ecologically important component of the rocky intertidal and subtidal communities along the Chilean coast (Castilla 1988, 1999). After 1 to 2 mo of intra-capsular development, the veliger larvae of this gastropod are released into the water column (Gallardo 1973, Castilla \& Cancino 1976), and then require from 3 to 12 mo of planktonic growth to reach competence (Gallardo 1973, DiSalvo 1988, Molinet et al. 2005). At competence, larvae of C. concholepas are mainly associated with the neustonic layer (DiSalvo 1988, Peña et al. 1994, Moreno et al. 1998, Poulin et al. 2002a,b, Manríquez et al. 2004, Molinet et al. 2005, 2006, 2008) and display pediveliger behaviour (i.e. mixed behaviour alternating between crawling and swimming, Carriker 1990, DiSalvo \& Carriker 1994). Although much has been written on the biology of $C$. concholepas (see Castilla 1988, 1999, Castilla \& Defeo 2001, Manríquez et al. 2009), to date little information has been published concerning the behavioural traits of competent $C$. concholepas larvae (hereafter CCL) and their role in larval transport and the establishment of the early benthic stage of this species. The use of rafting as a means of long-distance dispersal in C. concholepas larvae has been suggested (Castilla \& Guiñez 2000), and has also been described for several other marine phyla (reviewed by Thiel \& Gutow 2005a). However, the ability of CCL to adhere to floating substrata and use it as a means of transport has not yet been investigated. Thus it is possible that the production of a mucous thread by swimming CCL (DiSalvo 1988) could be a mechanism by which they adhere to floating substrata that has accumulated at surface convergence zones or slicks (i.e. floating algae, driftwood, man-made objects) and so enhance their rafting capacity.

In this study, under laboratory conditions, we investigated the swimming behaviour of CCL in response to vectors such as geotaxis, water flow and settlement cues (i.e. mussels and barnacles). Our laboratory experiments were complemented by field sampling in inner-nearshore waters (ca. 0.1 to $0.5 \mathrm{~km}$ from the coastline) designed to examine the relationship between diurnal and nocturnal abundances of CCL in the water column. Coastal CCL were collected to assess the relationship between their abundances and floating substrata that may serve as a complementary mechanism to enhance dispersal through rafting. Behaviours exhibited by larvae in confined containers cannot necessarily be extrapolated to those that they may display in nature; however, larval behavioural traits obtained under controlled conditions may help to determine CCL distribution in coastal environments and the establishment of the early benthic life of Concholepas concholepas after settlement (dispersal and recruitment niche, sensu Young et al. 2005), and might also provide useful information for future restocking and management programmes or the aquaculture of C. concholepas.

\section{MATERIALS AND METHODS}

Field sampling 1. Larval abundance and floating substrata. CCL were collected intermittently between 1990 and 2009 from surface tows using a plankton net in El Quisco $\left(32^{\circ} 33^{\prime} \mathrm{S}, 71^{\circ} 41^{\prime} \mathrm{W}\right)$ and between 2002 and 2004 in El Way $\left(23^{\circ} 42^{\prime} \mathrm{S}, 70^{\circ} 26^{\prime} \mathrm{W}\right)$, in central and northern Chile, respectively. Samples were collected between September and January in El Quisco and between December and January in El Way, matching the months of peak abundances of CCL (Poulin et al. 2002a). Samples were collected by towing a surface plankton net with a cross section of $0.8 \times 0.6 \mathrm{~m}$ at the open end, $1 \mathrm{~m}$ cloth length and $600 \mu \mathrm{m}$ mesh (DiSalvo 1988). The acquisition of competence was verified by the presence of a distinctive premetamorphic lip at the aperture rim of the protoconch (DiSalvo 1988). Tows were made in inner-nearshore waters, between ca. 0.1 and $0.5 \mathrm{~km}$ from the coast, with maximum water depths of ca. $20 \mathrm{~m}$. The number of CCL in each tow was expressed per unit of water sampled. Total sample volume was determined by multiplying the mouth area of the plankton net by the length of the tow which was measured by a flowmeter (General Oceanics ${ }^{\circledR}$ ) set in the mouth of the net. Abundance of CCL was correlated with total wet weight of both total flotsam retained by the sieve and total amount of the red complex algae Plocamium cartilagineum caught in each tow. When comparisons of CCL abundance between day and night were needed, 4 or 5 tows were carried out no more than $12 \mathrm{~h}$ apart on specific dates (see Table 1).

The samples taken from the central Chilean coast were transported to the laboratory of the Estación Costera de Investigaciones Marinas (ECIM) in Las Cruces $\left(33^{\circ} 30^{\prime} \mathrm{S}, 71^{\circ} 38^{\prime} \mathrm{W}\right)$, where most of the experiments were conducted. All CCL were individually assigned to $1 \mathrm{l}$ plastic containers filled with UV-treated, $0.45 \mu \mathrm{m}$ filtered seawater (FSW) and maintained on a laboratory bench at $14 \pm 2{ }^{\circ} \mathrm{C}$ under natural light photoperiodicity before being assigned 
to the corresponding experiments. At daily intervals, FSW was changed and the microalga Isochrysis galbana was added with a final concentration of 30 to 50 cells $\mu \mathrm{l}^{-1}$.

Field sampling 2. Adhesion of CCL to floating substratum as a potential rafting mechanism. To assess the potential relationship between the amount of floating debris and the abundance of CCL in inner nearshore zones, we collected additional samples in inner nearshore water areas with different abundances of debris: slick tows and non-slick tows (Shanks 1983, 1985) at El Quisco (September and December 2004) and El Way (December 2002, 2003 and January 2004). Sampling was conducted using the same methodology described in the previous section. Slicks were identified by the presence of floating debris associated with foam-covered water. In each location we employed 2 categories of non-slick tows, viz. shoreward or offshore with respect to the slick (no more than ca. $10 \mathrm{~m}$ away from the slick border). Moreover, to test whether CCL can reach settlement sites in the rocky intertidal zone by adhering to raft substrata (i.e. algae, debris and other), we sampled floating substrata, mainly fragments of Plocamium cartilagineum, from shallow rocky shore tide channels (ca. $10 \mathrm{~m}$ from shore and $1 \mathrm{~m}$ deep). Samples were collected in the vicinity of ECIM during November 2001. Samples (10 l plastic buckets) were taken from a large inner-nearshore patch of foam and floating substrata associated with foam slicks reaching the coast, and from nearby control areas of clear water without foam. For each sample $(n=7)$, the bucket was dragged twice through the surface of the water (ca. 20 l) to accumulate floating substrata, which was then concentrated in a $600 \mu \mathrm{m}$ mesh sieve to assess the abundance of CCL and floating substrata.

Laboratory experiments on larval behaviour. In the laboratory, photoperiodicity, thigmokinesis (tendency to cling to objects in the water; Fraenkel \& Gunn 1961) and turbulence experiments, we used flat-bottom glass test tubes, $40 \mathrm{~cm}$ high and $3.5 \mathrm{~cm}$ in diameter. Tubes were arranged vertically in transparent Plexiglas racks to minimise disturbance. In all experiments, FSW at 14 $\pm 2{ }^{\circ} \mathrm{C}$ and with 33 was used. The CCL were acclimatised to the glass tubes for $1 \mathrm{~h}$ before initiating observations. All experiments using glass tubes, except those related to photoperiodicity, were conducted in darkness, and observations were performed using a dim red light. Experiments using glass test tubes lasted $72 \mathrm{~h}$, and the larval behaviour was recorded at $1 \mathrm{~h}$ intervals. To assess larval position in the water column, tubes were divided into 4 sections (each $9.5 \mathrm{~cm}$ high). Larval activity was classified as swimming, hovering, crawling or resting on the bottom of the tubes.

Larval behaviour and measurements of swimming speeds. Observations of swimming behaviour were made by eye or assisted by a stereomicroscope. To assess larval upward and downward speeds, a video camera (SONY Handycam CCD-TVR608 Hi8) was placed in front of the tubes. The video images were processed and speeds calculated as the time required for an individual larva to traverse 1 or $2 \mathrm{~cm}$ in the water column.

Expt 1. CCL survivorship on rafting algae. To assess whether CCL can successfully survive grazing on the rafting algae, we deployed $8 \mathrm{CCL}$ inside individual 0.3 l glass beakers filled with FSW. In each beaker, we placed a small fragment of Plocamium cartilagineum as a source of food. In a control group, 8 CCL were placed in beakers filled with FSW without fragments of $P$. cartilagineum. The experiment was run for $14 \mathrm{~d}$, and the water was changed every second day. After $14 \mathrm{~d}$, settlement and metamorphosis were induced by exposing the surviving CCL to small rocks with recently settled aggregations of the barnacle Notochthamalus scabrosus (Manríquez et al. 2009).

Sixty individual larval trajectories, oriented parallel to the walls of the tubes, were considered for the speed calculations. To assess gravitational fall speeds, $11 \mathrm{CCL}$ were anaesthetised in a solution of menthol and seawater $\left(10 \mathrm{~g} \mathrm{l}^{-1}\right)$ until total withdrawal of the velar lobes. Larvae were placed in a glass cylinder (diameter $6.5 \mathrm{~cm}$ ) containing $2 \mathrm{l}$ of $\mathrm{FSW}$ at $14^{\circ} \mathrm{C}$. Gravitational fall speeds were timed over a distance of $20 \mathrm{~cm}$, and observations were made by eye. Active downward larval speeds were measured using a stopwatch from the surface down to the point where they entered the second section of the tube.

Expt 2. CCL photoperiodicity and circadian rhythm. The influence of different photoperiods on larval behaviour was evaluated (September to October 1991) by assigning groups of 6 CCL to each of the following treatments: (1) natural light:dark cycle (Control, $12 \mathrm{~h}$ light:12 h dark); (2) inverted light:dark cycle (Treatment 1, 12 h dark:12 h light); (3) constant light (Treatment 2); and (4) constant darkness (Treatment 3). Circadian behavioural rhythms can persist for several weeks in the laboratory in the absence of any environmental cues (Naylor 1988). Therefore, in this experiment, CCL were acclimatised in the laboratory for the altered photoperiod for $48 \mathrm{~h}$. During daylight hours, the experiments were illuminated with white overhead fluorescent lighting, from which the measured light intensity on the bench-top varied slightly around a mean value of $15 \mu \mathrm{E} \mathrm{m}^{-2} \mathrm{~s}^{-1}$, an intensity not designed to investigate phototaxis or mimic angular light distribution and intensity in the sea.

Expt 3. CCL and thigmotaxis. We conducted laboratory experiments to determine whether CCL display the ability to swim and to cling to floating objects. Moreover, we tested whether this behaviour is affected 
by different degrees of water movement. The observations were made during September and October 1991, in groups of $6 \mathrm{CCL}$ in individual tubes and applying the following treatments. Treatment 1: tubes filled with FSW only (Control); Treatment 2: FSW with small pieces of wood $(0.3 \mathrm{~cm}$ long $\times 0.02 \mathrm{~cm}$ wide $\times 0.02 \mathrm{~cm}$ high) floating in the water column); Treatment 3: FSW with small fragments (ca. $0.9 \mathrm{~cm}^{2}$ ) of Plocamium cartilagineum (suspended in the centre of the tubes with the aid of transparent monofilament line). Three separate experiments were conducted under 3 different water movement regimes: in the first, tubes were maintained immobile in the support rack. In the second and third, the rack bearing the tubes was placed on top of an adjustable orbital platform shaker set at 50 and $100 \mathrm{rpm}$, respectively. In an additional experiment (October 2006), we tested whether CCL adhere to floating substrata, such as fragments of $P$. cartilagineum, by active upward swimming followed by climbing, or as a consequence of a common surface convergence of CCL and substrata moved upward by the water current. Two groups of $12 \mathrm{CCL}$ were assigned individually to 2 Plexiglas aquaria $(331,30 \mathrm{~cm}$ high $\times 30 \mathrm{~cm}$ wide $\times 45 \mathrm{~cm}$ length) with the following treatment conditions: (1) floating substrata and still FSW and (2) floating substrata with an upward current. To achieve an upward current flow (ca. $0.2 \mathrm{l} \mathrm{s}^{-1}$ ), the aquarium was equipped with an electric water pump which generated a circular water current from the bottom of one side of the aquarium to the water surface on the other side. To avoid dragging larvae and fragments of algae through the pump, we placed a $600 \mu \mathrm{m}$ mesh across the side of the aquarium where the pump was placed. We deployed 20 fragments of $P$. cartilagineum as floating potential substrata for CCL in each aquarium. To ensure a similar surface area of $P$. cartilagineum in each treatment, we cut the algae to provide a surface area of approximately $2.5 \mathrm{~cm}^{2}$. The CCL were placed in the aquarium, acclimatised for $10 \mathrm{~min}$, after which the fragments of algae were introduced. The experiment was conducted overnight (00:00 to 03:00 h), and after $20 \mathrm{~min}$ exposure to the experimental conditions, we recorded whether each larva had adhered to the floating algae. In this experiment, we used CCL and fragments of $P$. cartilagineum collected at El Quisco. However, due to logistical problems, the experiment was conducted at the Laboratorio Costero de Recursos Acuáticos de Calfuco in Valdivia $\left(39^{\circ} 46^{\prime} \mathrm{S}, 73^{\circ} 23^{\prime} \mathrm{W}\right)$.

Expt 4. Mucous thread and CCL adhesion under different water movement and settlement cues. Two series of experiments (September to October 2009) were conducted at the Laboratorio Costero de Recursos Acuáticos de Calfuco in Valdivia with CCL collected in Antofagasta and transported to Valdivia within $24 \mathrm{~h}$ of collection. In the first experimental series, individual CCL $(\mathrm{n}=12)$ were randomly assigned to separate $25 \mathrm{~cm}$ high $2 \mathrm{l}$ glass beakers in which a clean air stone was placed near the bottom. Intense water movement was achieved by setting a high bubbling regime $\left(8 \mathrm{l} \mathrm{h}^{-1}\right)$ in half of the bottles. In the control ( $\mathrm{n}=12)$, no bubbling was used. Larvae were maintained under those conditions for $8 \mathrm{~h}$, after which time the observations were conducted. Each larva was gently touched with a soft artist's brush to determine whether the production of the mucous thread assisted adhesion to the brush. In the second experimental series, we tested the combined effect of water movement and settlement cues in triggering adhesion of CCL to the water tension. Water movement was achieved by using a rack system of swinging paddles in which the Plexiglas paddles pivoted inside 11 glass beakers. An electric rotary motor allowed us to control the speed of the pivoting frequency, which was set at 0 (control), 0.1 (Treatment 1) and 0.4 (Treatment 2) sweeps $\mathrm{s}^{-1}$. For each water movement regime, we used small rocks bearing ca. 100 recently settled barnacle aggregations of Notochthamalus scabrosus and bare rocks of an equivalent size which served as controls. For each water condition, we used $8 \mathrm{CCL}$ assigned to individual $1 \mathrm{l}$ glass beakers filled with $0.45 \mu \mathrm{m}$ seawater. Larvae were maintained there for $6 \mathrm{~h}$, and then the electric motor was switched off, allowing us to conduct the observations of larval behaviour during nighttime hours. From direct observations, we noted 5 different behavioural patterns: crawling on the rocks, crawling on the surface of the rearing beakers, swimming, drifting and taking advantage of the water surface tension to remain at the surface. Drifting larvae were considered to be those moving with the water current with or without the velum extended from the protoconch.

Expt 5. Settlement cues and swimming of CCL. This experiment was conducted to determine whether swimming of CCL is modulated by the presence of settlement cues (September to October 2006). Larvae were assigned individually to glass beakers filled with 21 of $0.45 \mu \mathrm{m}$ FSW with the following treatments in which prey were offered at the bottom of the aquaria: ca. $200 \mathrm{~g}$ of live specimens of the mussel Semimytilus algosus of ca. $0.2 \mathrm{~mm}$ in length (Treatment $1, \mathrm{n}=10$ ) and small rocks bearing ca. 150 recently settled barnacles Notochthamalus scabrosus (Treatment 2, $\mathrm{n}=10$ ). As a control group, we used beakers without prey $(\mathrm{n}=10)$. S. algosus were used in Treatment 1 because they induce settlement in Concholepas concholepas (Manríquez et al. 2004, 2008, 2009) and are the preferred prey for early post-metamorphic C. concholepas under laboratory and field conditions (Dye 1991, Méndez \& Cancino 1990). Rocks with N. scabrosus were 
used because small settlers of C. concholepas (ca. 0.2 to 0.5 of peristomal length) commonly occur in the microhabitat of the rocky intertidal zone (Manríquez et al. 2009). In the beakers, prey were allowed to acclimatise for $2 \mathrm{~h}$ before CCL were added. Larval activity was monitored continuously for periods of $3 \mathrm{~h}$ during the night (00:00 to 03:00 h) and day (10:00 to 13:00 h), using a dim red light to make nocturnal observations. During the observations, larval activity was classified as swimming or crawling, and a standardised number of swimming displacements towards the water surface per hour were used to compare the treatment and control conditions. Larvae taking advantage of the water surface tension to remain at the surface were gently disturbed with a soft artist's brush to induce them to sink.

Statistical analysis. Natural abundances of CCL and the number of swimming displacements were analysed by 1-way ANOVA. When data deviated from normality and/or did not fit a normal distribution after transformation, we used non-parametric statistics. A 2-way ANOVA was used to determine whether the number of larvae swimming or adhering to substrate differed between intensities of water movement. Rhythmicity in the photoperiodicity experiment was determined by plotting autocorrelation coefficients calculated at $1 \mathrm{~h}$ lag intervals (= sampling intervals) as a function of lag intervals (Broom 1979). Peaks in the autocorrelation plots exceeding the $95 \%$ confidence intervals were considered to indicate statistically significant rhythmicity at $\mathrm{p}<0.05$. To detect possible cyclical behaviour, period lengths were calculated with spectral Fourier analysis, which aims to identify the dominant frequency of an apparently periodic signal (Dowse 2007). The proportions of CCL adhering to the experimental substrata with and without upward seawater current were compared by a 2-proportion Z-test (Zar 1999).

\section{RESULTS}

\section{Field sampling 1. CCL larval abundance and floating substrata}

In the shallow inner nearshore collection sites, CCL were found in diurnal and nocturnal surface tows. When both diurnal and nocturnal inner nearshore tows were made, no more than $12 \mathrm{~h}$ apart, significantly more larvae were found in nocturnal tows (Table 1). In diurnal tows, a positive linear correlation was found between the amount of flotsam and both the amount of Plocamium cartilagineum and the number of CCL (Fig. 1a,b). Similarly, in diurnal tows, a positive linear correlation was found between the amount of floating $P$. cartilagineum and the number of CCL larvae (Fig. 1c). In nocturnal tows, the only significant correlation found was that between the amount of flotsam and the amount of $P$. cartilagineum (Fig. 1d). No correlation was found between the amount of flotsam and the number of CCL (Fig. 1e) or between the amount of $P$. cartilagineum and the number of CCL (Fig. 1f). During the analyses of the plankton samples in the laboratory, CCL were frequently found adhering to fragments of $P$. cartilagineum and empty tubes of Chaetopteridae polychaetes (Fig. 2e,f) and other floating biotic and abiotic substrata, such as wood, fragments of fronds and holdfasts, plastic, candy wrappers and fragments of polystyrene packing, amongst others.

\section{Field sampling 2. CCL adhesion to floating substratum as potential rafting mechanisms}

In Antofagasta, significantly more CCL were found within tows through the foam slicks than in the shoreward or offshore tows (Table 2). On average, ca. 35 and 110 times fewer CCL were found in the offshore and shoreward tows, respectively, than in the slick tows. In El Quisco, CCL were only found in tows through the foam slicks and on the shoreward side. However, average numbers of CCL were significantly higher in the foam slicks. No CCL were found in the offshore tows (Table 2). In samples collected from shallow intertidal tide channels (using buckets), CCL were only found in those samples that contained floating Plocamium cartilagineum. Average $( \pm \mathrm{SE})$ numbers of CCL collected per quantity of $P$. cartilagineum were: $0.067 \pm$ 0.021 larvae $^{-1}$ in September $(\mathrm{n}=7) ; 0.051 \pm 0.027$ lar-

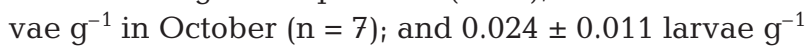
in November $(n=7)$. No CCL were found in samples from clear shallow waters. 

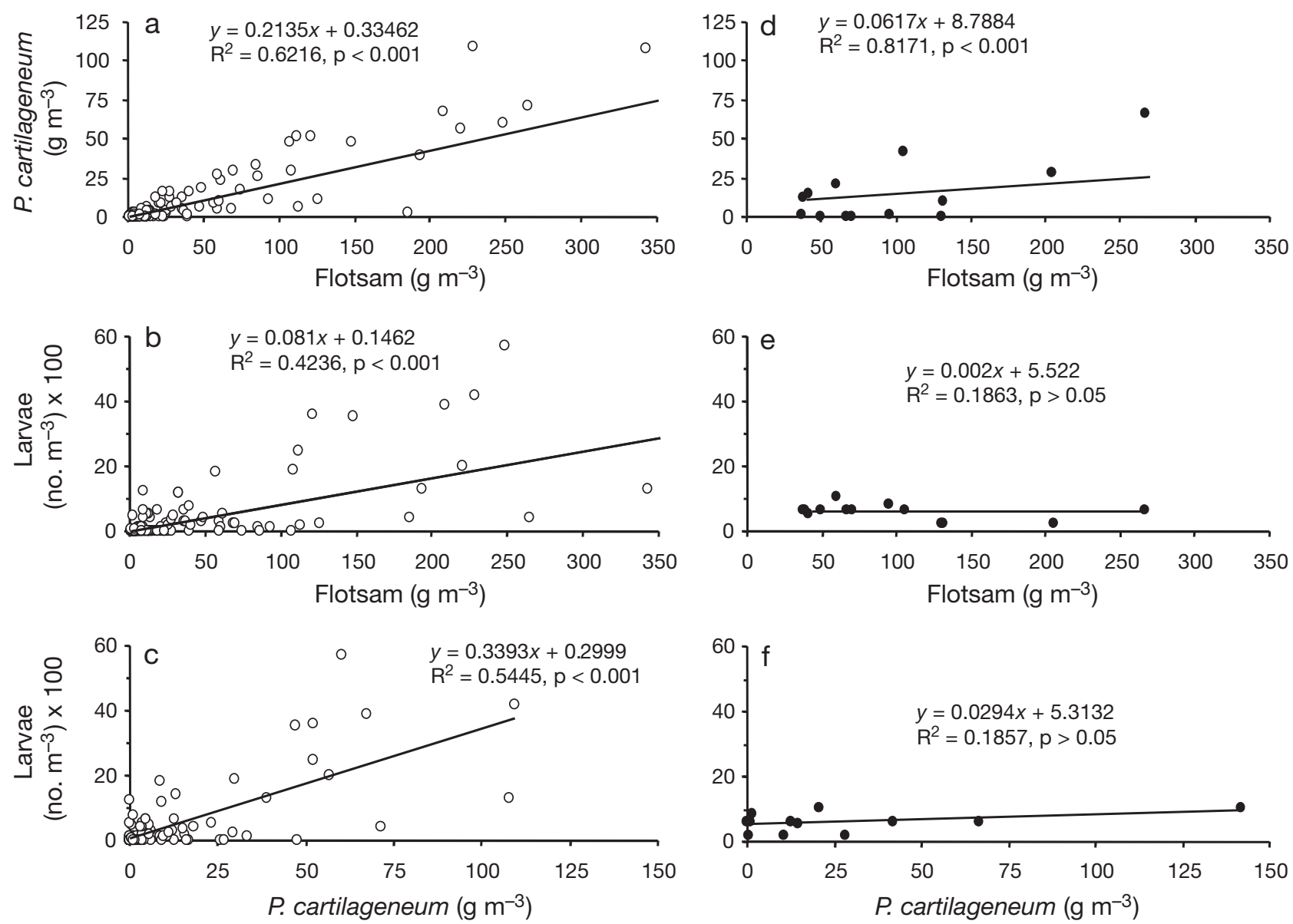

Fig. 1. Concholepas concholepas. Relationships between the amount of flotsam, Plocamium cartilagineum and the number of competent larvae in diurnal and nocturnal tows. White (left panels) and black (right panels) circles are diurnal and nocturnal tows, respectively

\section{Larval behaviour and measurements of swimming speeds}

During swimming in the laboratory, CCL retained the 4 large ciliated velar lobes (ca. $4 \mathrm{~mm}$ long, Fig. 2b) expanded and oriented upward lifting and dragging the protoconch (ca. $1.7 \mathrm{~mm}$ long, Fig. 2a,b) with the umbo pointing downward. Larvae displayed the 'hop and sink' method of locomotion in which they swam alternatively upwards and downwards (Bainbridge 1961). The upward swimming speed ranged from 0.17 to $0.60 \mathrm{~cm} \mathrm{~s}^{-1}$ (average $\pm \mathrm{SD}$ speed $=0.41 \pm 0.11 \mathrm{~cm} \mathrm{~s}^{-1}$; $\mathrm{n}=60$ ). Once the velar lobes made contact with the water surface, they were flapped and the larvae swam downward maintaining the velar arms expanded. However, occasionally after the velar lobes made contact with the water surface, total withdrawal of the velar lobes was observed and the larvae sank downwards. Downward swimming speed ranged from 0.32 to $0.69 \mathrm{~cm} \mathrm{~s}^{-1}$ (average $=0.48 \pm 0.09 \mathrm{~cm} \mathrm{~s}^{-1} ; \mathrm{n}=60$ ). Maxi. mum speeds were obtained just after larvae made contact with the water surface (average $=0.75 \pm 0.12 \mathrm{~cm}$ $\mathrm{s}^{-1} ; \mathrm{n}=60$ ). Larvae also attached to the surface water tension using their foot (Fig. 2c) or by hanging down from the water surface by a mucous thread (also see DiSalvo 1988) secreted from a small hole in the base of the foot (Fig. 2g). Larvae were also observed to float using air bubbles captured with their foot (Fig. 2d), a method described by DiSalvo (1988) for CCL. While floating, the larvae fully withdrew their velar lobes inside the protoconch in a resting attitude (Fig. 2c). Gravitational fall velocities of the anaesthetised larvae ranged between 1.45 and $2.89 \mathrm{~cm} \mathrm{~s}^{-1}$ (average $=2.08 \pm$ $0.38 \mathrm{~cm} \mathrm{~s}^{-1} ; \mathrm{n}=11$ ).

\section{Expt 1. CCL survivorship on rafting algae}

In the laboratory, all CCL $(\mathrm{n}=8)$ maintained in FSW for 2 wk with fragments of Plocamium cartilagineum survived, successfully settled and metamorphosed when exposed to rocks covered with barnacles. However, no CCL $(\mathrm{n}=8)$ survived in the control condition without fragments of $P$. cartilagineum. 

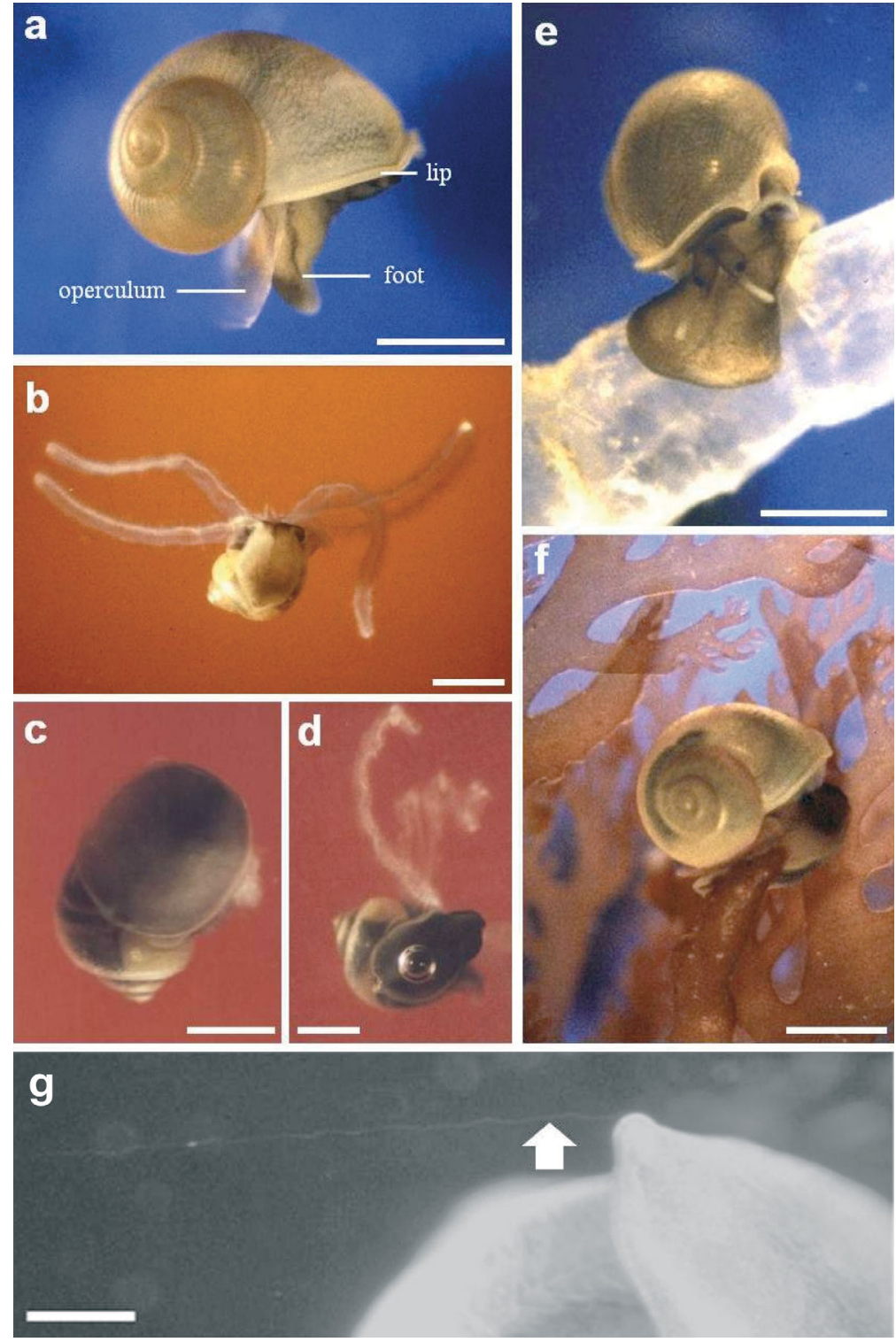

Fig. 2. Concholepas concholepas. Photographs of competent larvae. (a) Lateral view showing the upturned lip on the edge of the shell aperture denoting competence, the foot and the larval operculum; (b) free-swimming competent larvae showing expanded velar lobes lifting and dragging the protoconch; (c) larva attached to the water surface using its foot; (d) larva floating using bubbles captured with its foot; larva adhering to (e) empty tubes of Chaetopteridae polychaetes and to (f) fragments of the red algae Plocamium cartilagineum; (g) a hyaline mucous thread emerging from the posterior end of the larval foot. The white arrow in $(\mathrm{g})$ depicts the mucous thread. All scale bars $=1000 \mu \mathrm{m}$

\section{Expt 2. CCL photoperiodicity and circadian rhythm}

Regardless of the experimental photoperiod, the maximum numbers of swimming CCL under still water laboratory conditions were observed during the hours coinciding with natural darkness (Fig. 3). Larvae were observed swimming vertically throughout the entire wa- ter column in the tubes, swimming rapidly to the surface and sinking passively to the bottom. However, during the day, larvae stayed at the bottom of the tubes, crawling or making small excursions upwards that seldom allowed them to reach the upper part of the water column. Regardless of observation time, larval displacement from the water surface to the bottom was achieved by either swimming or passive sinking. In all 4 experimental photoperiods used, the Fourier analysis detected a swimming period length of ca. $24 \mathrm{~h}$. These analyses revealed a significant negative autocorrelation (i.e. above the $95 \%$ confidence limit) only between 9 and $11 \mathrm{~h}$ (time spent swimming). Beyond the peak of activity at $11 \mathrm{~h}$, autocorrelation coefficients never reached significance in the explored range of hours.

\section{Expt 3. CCL and thigmotaxis}

The swimming activity of CCL was concentrated mainly at night (Fig. 4), and 100\% of larvae were recorded swimming for 2 to $12 \mathrm{~h}$ periods. When floating substrata were made available at the surface of the experimental tubes, between 20 to $30 \%$ of the larvae adhered to the substrata: larvae remained adhered to wooden substrata for a maximum of $3 \mathrm{~h}$ and adhered continuously to fragments of Plocamium cartilagineum for up to $36 \mathrm{~h}$. At night, in tubes agitated at $50 \mathrm{rpm}, 100 \%$ of larvae were observed actively swimming for a period of between 2 and $12 \mathrm{~h}$. When substrata were made available at the surface, up to $30 \%$ of larvae adhered to the wooden substrata and up to $50 \%$ to $P$. cartilagineum: they remained adhered to pieces of wood for up to $6 \mathrm{~h}$ and adhered continuously to fragments of $P$. cartilagineum for up to $40 \mathrm{~h}$. Water movement had a negative effect on nocturnal swimming activity when the tubes were agitated at $100 \mathrm{rpm}$. At this speed, swimming activity was reduced to $66 \%$. No larvae were observed adhering to pieces of wood; however, they adhered to fragments of $P$. cartilagineum for up to $12 \mathrm{~h}$. A 2-way ANOVA on the average number of adhered CCL larvae indicated a significant effect of floating substrata, water movement and the interaction between them. A similar analysis of the average number of swimming CCL detected a significant effect of water movement. However, the presence of floating substrata 
Table 2. Concholepas concholepas. Abundance of competent larvae in diurnal tows made in (slick tows), and adjacent to, nearshore frontal foam slicks. Waters adjacent to the foam slicks were sampled for offshore and shoreward tows (non-slick tows). Data are mean number of larvae ( $\pm \mathrm{SE}$; number of tows) per $100 \mathrm{~m}^{3}$ and were compared using Kruskal-Wallis analyses of variance

\begin{tabular}{|lcccrrr|}
\hline Date & Slick tows & Offshore tows & Shoreward tows & df & $\chi^{2}$ & $p$ \\
\hline Antofagasta, Dec 2002 & $45.67(7.32 ; 4)$ & $0.39(0.39 ; 4)$ & $1.31(0.62 ; 4)$ & 2 & 8.46 & 0.0145 \\
Antofagasta, Dec 2003 & $35.33(8.86 ; 4)$ & 0 & $0.67(0.38 ; 4)$ & 2 & 7.33 & 0.0256 \\
Antofagasta, Jan 2004 & $73.33(24.66 ; 4)$ & 0 & 0 & 2 & 10.46 & 0.0054 \\
El Quisco, Sep 2004 & $5.37(0.13 ; 4)$ & 0 & $0.30(0.30 ; 4)$ & 2 & 9.37 & 0.0092 \\
El Quisco, Dec 2004 & $10.03(2.33 ; 4)$ & 0 & $1.17(0.44 ; 4)$ & 2 & 9.42 & 0.0090 \\
\hline
\end{tabular}

and their interaction effect with water movement was not significant (Table 3). In agitated seawater, we observed a transparent mucous thread originating from the posterior end of the larval foot (Fig. 2g). In the second experiment, significantly more CCL ended up adhered to $P$. cartilagineum with an upward seawater current $(85 \%, \mathrm{n}=20)$ than in the still seawater treatment $(30 \%$, $\mathrm{n}=20 ; Z$-test for 2 proportions, $Z=3.19, \mathrm{p}<0.05$ ).

Expt 4. CCL mucous thread and larval adhesion under different water movement and settlement cues

Mucous threads that allowed CCL to hang from floating substrates or from the water tension were up to

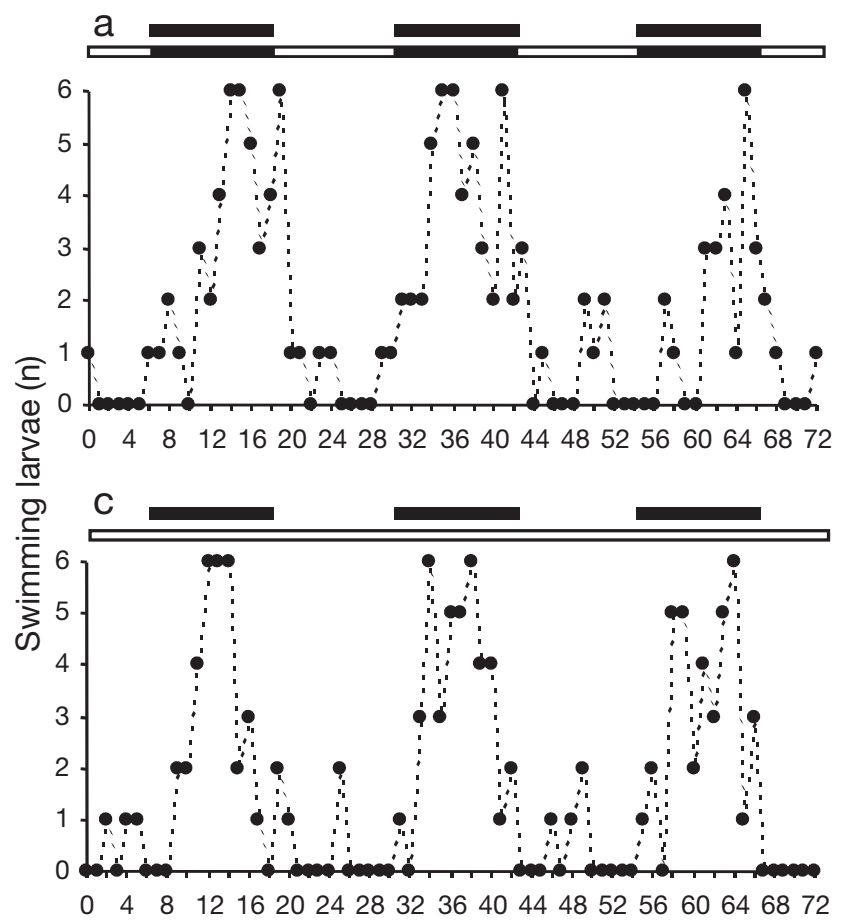

$5 \mathrm{~cm}$ long. Contact between the soft brush and the larvae resulted mostly in the larva attaching to the brush by a mucous thread. In the agitated water treatment, $92 \%$ of larvae formed a mucous thread $(n=12)$. However, in still conditions, only $8 \%$ CCL displayed the same response $(n=12)$. On occasion, once the brush was shaken and lifted, mucous threads as long as 30 to $40 \mathrm{~cm}$ were observed. In the second experimental series, regardless of the water movement treatment and not taking into account the least represented behaviour (glass crawling, GC), the behavioural responses were significantly different in the presence or absence of barnacles $\left(\chi^{2}: 39.83\right.$, df $=3$, p $<0.0001$, Fig. 5). On the other hand, regardless of the presence of barnacles and not considering the least represented
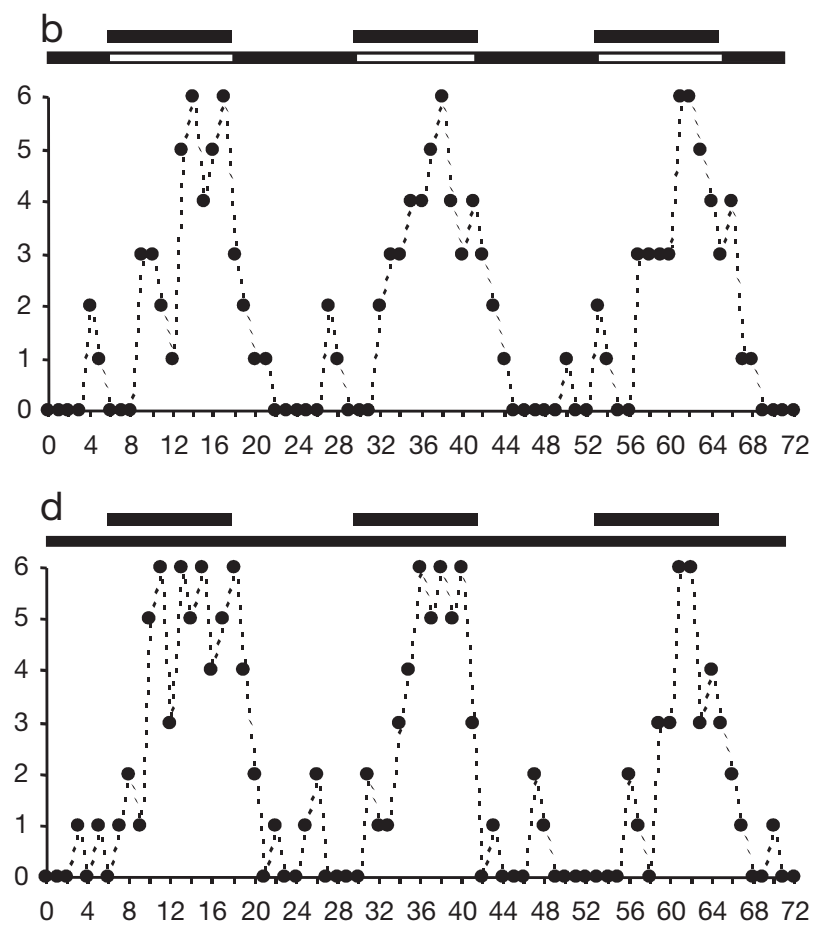
Time (h)

Fig. 3. Concholepas concholepas. Seventy-two hour records of swimming behaviour in competent larvae during 4 different photoperiods: (a) natural light:dark cycle; (b) inverted light:dark cycle; (c) constant light; and (d) constant darkness. Observations were for $72 \mathrm{~h}$ at $1 \mathrm{~h}$ intervals using 6 newly captured competent larvae in each treatment, with 1 larva assigned to each test tube. The horizontal white and black bars immediately above the graphs represent hours of light and darkness, respectively, according to the treatment. The 3 horizontal and black bars at the top of the figure represent the natural nighttime hours 

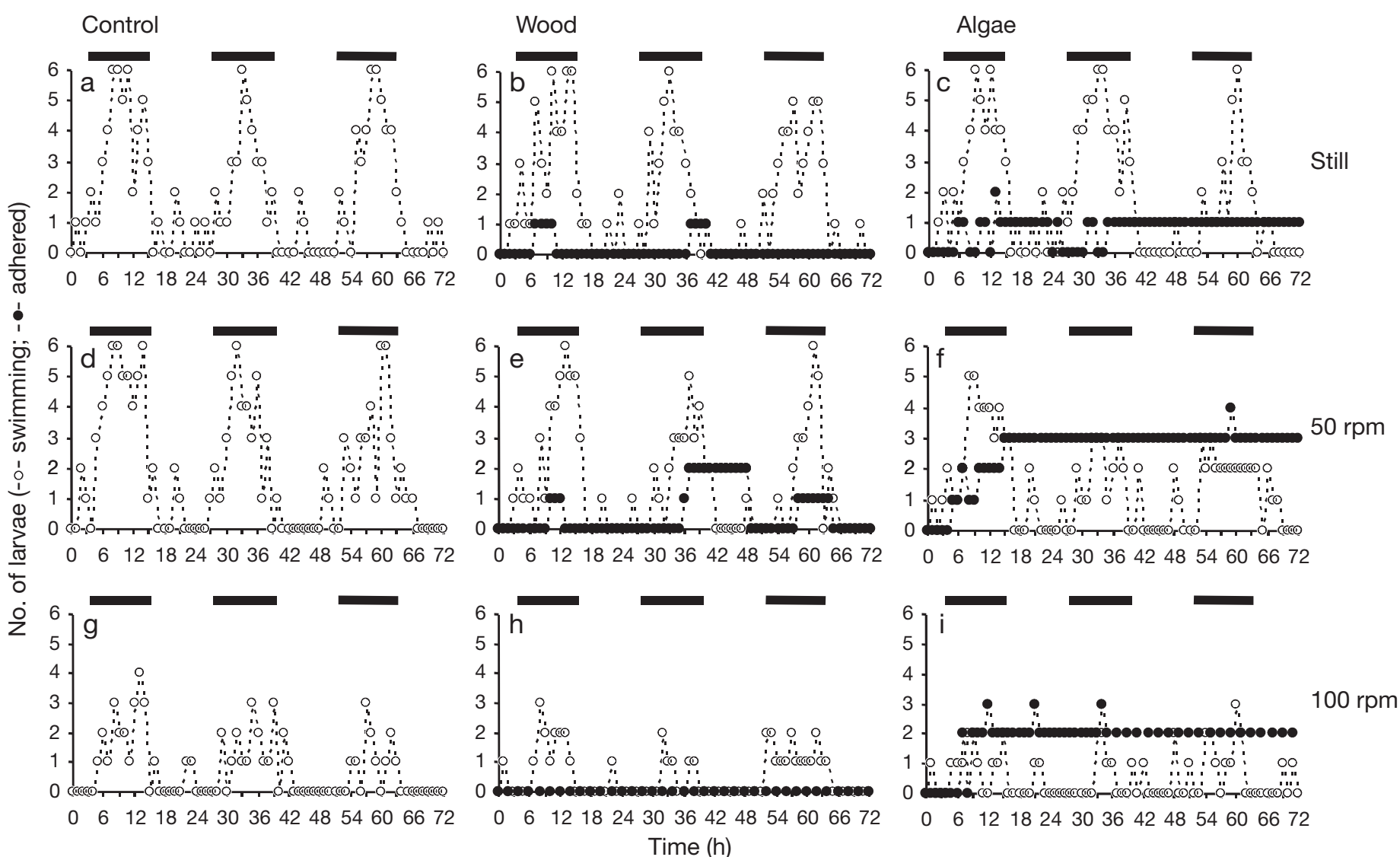

Fig. 4. Concholepas concholepas. Expt 3: effect of water movement and the presence of floating objects on the swimming behaviour of competent C. concholepas larvae (CCL). Behaviour was assessed by placing CCL, 1 individual randomly assigned to each tube, in the water columns of test tubes. Water movement was simulated by placing the test tubes on an orbital shaker: (a-c) still; $(\mathrm{d}-\mathrm{f}) 50 \mathrm{rpm}$; and $(\mathrm{g}-\mathrm{i}) 100 \mathrm{rpm}$. The presence/absence of floating objects was as follows: $(\mathrm{a}, \mathrm{d}, \mathrm{g}) 0.45 \mu \mathrm{m}$ filtered seawater only (Control); (b,e,h) small pieces of floating wood (Treatment 1); and (c,f,i) small fragments of Plocamium cartilagineum suspended in the centre of the tubes with the aid of a transparent monofilament line (Treatment 2). White circles are swimming larvae and black circles are larvae attached to floating objects. The 3 horizontal and black bars at the top of the figure represent the natural nighttime hours

behaviour (GC), the behavioural responses were significantly different between water movement treatments $\left(\chi^{2}: 21.634, \mathrm{df}=6, \mathrm{p}<0.0001\right.$, Fig. 5). In general, in the absence of barnacles, swimming was the most recorded behaviour. In the presence of barnacles, however, crawling on the surface of the rocks was more frequently observed. Direct observations during the experiments detected the active participation of the CCL during the initial phase of mucus drifting, indicated by the secretion of a hyaline mucous thread through the pedal pore before the CCL were carried away by the water currents.

\section{Expt 5. Settlement cues and swimming of CCL}

Overnight, significantly more swimming displacement events by CCL were recorded per hour in the control than in the treatments with mussels or barna- cles $\left(F_{2,29}=97.95, \mathrm{p}<0.001\right.$, Fig. 6$)$. On average, ca. 65 times more upward displacements were observed in the control. When not swimming at night and close to

Table 3. Concholepas concholepas. Expt 3: results of 2-way ANOVAs on the effect of presence of floating substrata and water movement on the number of adhered and swimming competent larvae. Numbers of larvae were averaged across the $72 \mathrm{~h}$ of observations in each treatment (see 'Materials and methods' for details)

\begin{tabular}{|lccccc|}
\hline & df & SS & $F$ & $p$ \\
\hline Adhered larvae & & & & \\
Substrate & 2 & 401.86 & 918.38 & $<0.0001$ \\
Water movement & 2 & 64.97 & 148.47 & $<0.0001$ \\
Substrate $\times$ Water movement & 4 & 76.54 & 87.46 & $<0.0001$ \\
Swimming larvae & & & & \\
Substrate & 2 & 14.73 & 2.83 & 0.0597 \\
Water movement & 2 & 190.45 & 36.60 & $<0.0001$ \\
Substrate $\times$ Water movement & 4 & 8.06 & 0.78 & 0.5418 \\
\hline
\end{tabular}



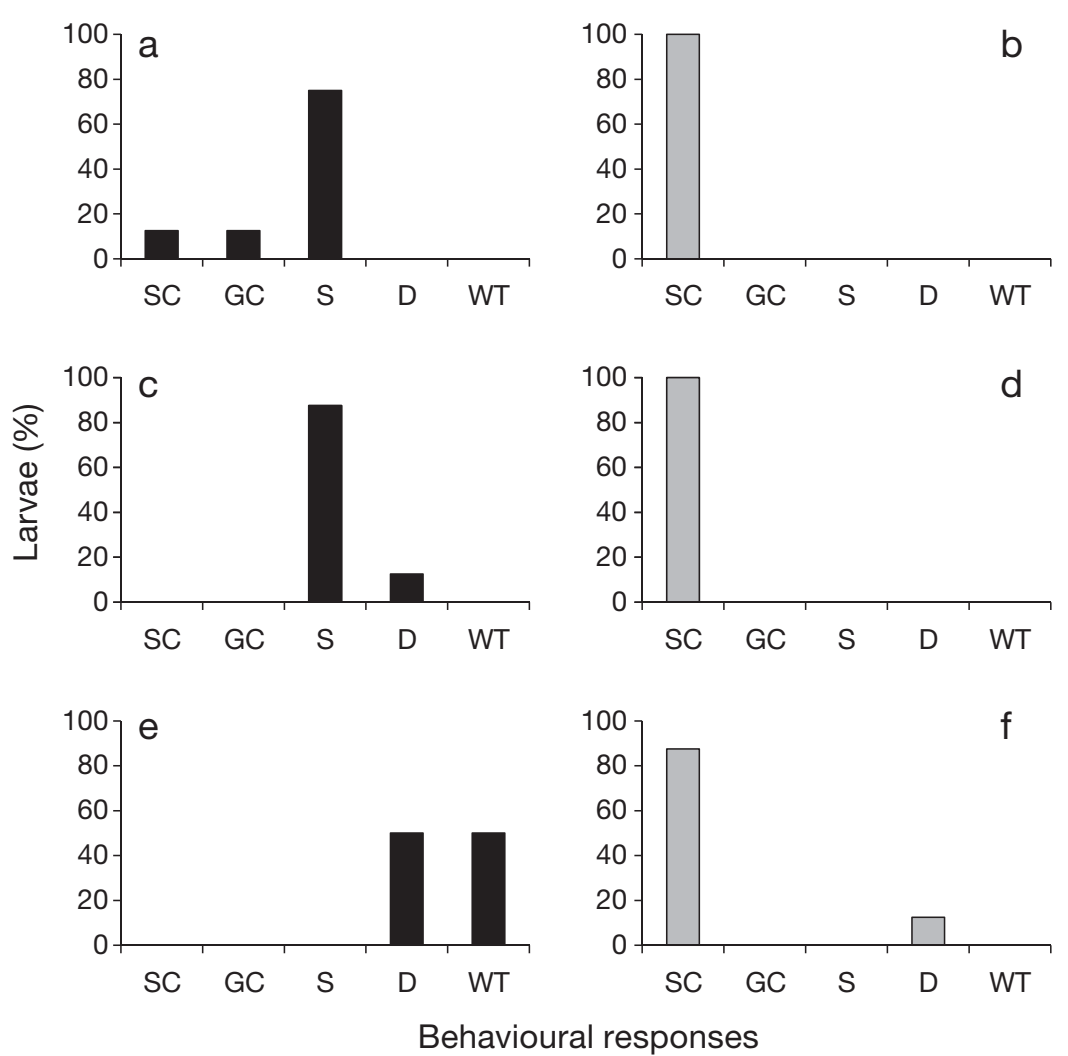

Fig. 5. Concholepas concholepas. Percentage of competent C. concholepas larvae (CCL) in the absence (black, left panels) and presence (grey, right panels) of settlement cues displaying different behaviours (SC: stone crawling, GC: glass crawling, S: swimming, D: drifting, WT: taking advantage of the water tension) under 3 water movement regimes (pivoting frequencies): $(\mathrm{a}, \mathrm{b})$ still, $(\mathrm{c}, \mathrm{d})$ low and $(\mathrm{e}, \mathrm{f})$ high. See Expt 4 in 'Materials and methods' for further details

the water surface, CCL were observed crawling, resting on the surface of the presented prey, or swimming close to them on the bottom. During the daylight hours, swimming displacement was rarely observed, and no significant differences between the treatments and the control were found $\left(F_{2,29}=0.45, \mathrm{p}>0.05\right.$, Fig. 6).

\section{DISCUSSION}

\section{Natural abundance of CCL}

Presence of CCL in the water column during the sampling months agrees with previous reports in the same geographic area (Poulin et al. 2002a,b). Similarly, the present study is in good agreement with the presence of egg capsules (Manríquez \& Castilla 2001) and recruits (Martínez \& Navarrete 2002) of the species in the same area before and after the Concholepas concholepas larval season. The high abundances of CCL found in inner-nearshore shallow waters, within ca. $0.5 \mathrm{~km}$ of the shore, during nocturnal tows suggest that our laboratory results are in agreement with observed nocturnal vertical migration. However, there is evidence that in deeper waters (ca. 40 to $100 \mathrm{~m}$ ) and further offshore (ca. 1 to $5 \mathrm{~km}$ from the coast), this pattern of vertical migration and CCL abundance may be reversed, with higher abundances during diurnal hours (Poulin et al. 2002b).

\section{CCL adhesion to floating substratum as potential rafting mechanisms}

The ability of CCL to adhere to floating substrata and raft is supported by the following results: the positive correlation between the abundance of CCL and floating substrata in diurnal tows, higher abundances of CCL in inner nearshore foam slicks compared to nonslicks, the higher abundances of CCL on coastally 
derived algal debris compared to clean water samples, and the capacity of CCL to adhere to buoyant substrata in laboratory conditions. In the literature, rafting generally involves passive transport with a low energy expenditure by post-larval stages, juveniles and small adults (Anderson 1971, Levinton 1979, Highsmith 1985, Martel 1988, Martel \& Chia 1991a,b, Thiel \& Gutow 2005a, Cañete et al. 2007). However, our results suggest that rafting may also be used by late larval stages such as CCL in nearshore environments to assist them in reaching the coast. Rafting by Proclamium cartilagineum is consistent with the capacity for rafting described for other species of algae (Edgar 1987, van der Merwe \& McLachlan 1987, Thiel \& Gutow 2005b, Vandendriessche et al. 2007). Under laboratory conditions, fresh fragments of $P$. cartilagineum maintained in running seawater and exposed to natural light regimes with seawater temperature ranging between 10 and $25^{\circ} \mathrm{C}$ began the degradation process after ca. $15 \mathrm{~d}$, and total degradation occurred by ca. $30 \mathrm{~d}$ (P. H. Manríquez pers. obs.). This suggests that the time that CCL can spend rafting on fragments of $P$. cartilagineum will depend in part on the integrity of this substratum.

The ability of early post-settlers of Concholepas concholepas to feed on biofilm has been reported in the literature, even after active predation on live mussels has started (DiSalvo 1988). Therefore, it is possible that rafting CCL may switch from filter feeding (Vargas et al. 2006a) to feeding on small prey associated with the raft substrata or herbivory, as suggested by DiSalvo (1988). This is supported by the presence of a fully developed radula in CCL (P. H. Manríquez pers. obs.) and their high survivorship when maintained in FSW with fragments of Proclamium cartilagineum (present study). However, the potential for early herbivory in this carnivorous species needs further investigation. $P$. cartilagineum is a cosmopolitan species (Dixon \& Irvine 1977), which occurs from the low intertidal down to a depth of $30 \mathrm{~m}$ (Lancellotti \& Trucco 1993), and whose detached foliaceous branches are commonly found in inner nearshore coastal foam slicks or forming part of massive aggregations of coastally derived algae found off the coast of central Chile (P. H. Manríquez pers. obs.). Therefore, this substratum is widely available as potential raft substrate for other early stages of invertebrates. However, our study demonstrates that CCL adhere to biotic and abiotic substrata, suggesting that adhesion is not selective.

Off central Chile, it has been suggested that internal tidal bore warm fronts could play an important role in the onshore transport of neustonic invertebrate larvae (Vargas et al. 2004), a mechanism also described for other inshore environments (Pineda 1991, Largier 2002). Between 10:00 and 23:00 h and during the sea- son when CCL were collected in central Chile, the predominant upwelling-favourable winds were primarily from the southwest-west; these push water both onshore and along-shore (Narváez et al. 2004). Therefore, surface currents with the potential for transporting floating substrata and the associated rafting organism to the coast may be an important physical transport mechanism. In the same vein, the wind-driven shoreward transport of CCL by Langmuir lines (Kingsford 1990) has also been suggested (Moreno et al. 1998). Additionally, we suggest that CCL may also be carried shoreward in surface foam slicks generated by tidally forced internal waves (Shanks 1983, 1985, 1986, Pineda 1991), adhered to buoyant substrata accumulated on frontal foam lines (Shanks et al. 2000). Similarly, high abundances of barnacle nauplii found at river plume fronts in central Chile suggest that in nearshore environments, transport of flume-aggregated larvae to onshore habitats can be enhanced by local factors (Vargas et al. 2006b).

The information available concerning other mucousthread drifting gastropods (Lane et al. 1985, Martel \& Chia 1991a,b) indicated the active participation of the foot-raising behaviour in the initiation of the drifting behaviour during post-metamorphic stages. However, our results expand this behaviour to larval stages. Foot-raising, mucous thread production and drifting behaviour has also been recorded under laboratory conditions in post-metamorphic stages of Concholepas concholepas associated with self-righting behaviour (P. H. Manríquez pers. obs.), suggesting that this behaviour might play an important role during the ontogenetic plankton-benthic transition, allowing a rapid relocation from unfavourable microhabitats or reducing the time spent by CCL in a vulnerable upsidedown position after dislodgement.

\section{Photoperiodicity, thigmotaxis and turbulence}

Despite the limited evidence of endogenous rhythms in zooplankton (Forward 1988), our results showed a marked endogenous nocturnal rhythm in the swimming activity of CCL under several different laboratory conditions of photoperiod and water movement. This suggests the existence of an internal rhythm as has been described for other veligers that swim up into the plankton at night to feed, and passively sink below the photic zone during daytime. Such behaviour of reverse diel migration may be advantageous in reducing predation and exposure to harmful UV rays, and perhaps enables larvae to take advantage of lower metabolic costs at cooler depths. Withdrawal of the velar lobes and passive sinking, similar to that observed with anaesthetised CCL, was frequently observed in our 
study. Gravitational fall speeds of the anaesthetised CCL with a withdrawn velum were several times greater than larval upward and downward swimming speeds. These differences have been interpreted as a mechanism that may allow veliger larvae to accumulate close to the bottom (Bayne 1964). By using this mechanism, CCL may be transported both passively and rapidly near the seabed and avoid offshore transport. According to our measurements of vertical swimming velocities, and despite interactions between small-scale turbulence and swimming, in shallow waters of ca. $20 \mathrm{~m}, \mathrm{CCL}$ would need about $1 \mathrm{~h}$ to reach the water surface by exclusively swimming upwards. Therefore, in inner-nearshore environments, CCL would stay at the surface at night, reducing the risk of predation and enhancing wind or surface current dispersion towards the coastal habitats. In contrast, in offshore deeper water (ca. 1 to $5 \mathrm{~km}$ from the coastline), depending on the depth, CCL would theoretically need ca. 3 to $7 \mathrm{~h}$ to reach the water surface. Under such conditions, it is highly probable that CCL could not reach the surface by exclusively swimming upwards. Therefore, as suggested, upwelling events could occasionally move the CCL to the surface (Poulin et al. 2002b). In the laboratory, CCL kept in still and agitated seawater alternately swam up and sank, as has been described for other veligers (e.g. Cragg \& Gruffydd 1975, Hidu \& Haskin 1978). This highlights the fact that gravity is an important vector cue for the orientation of CCL.

Although laboratory conditions used in our experiments are highly artificial (i.e. water agitated with air bubbles), our results clearly show that under such conditions CCL are able to cling onto floating substratum both in still water and under moderate water movement. The negative effect of high water movement on CCL swimming mirrors the sinking behaviour found in competent larvae of other coastal gastropods, such as Ilyanassa obsoleta, exposed under laboratory conditions to water turbulence (Fuchs et al. 2004, 2007). This suggests that through sinking, CCL reaching turbulent and coastal shallow waters may improve their chances of settling by descending closer to the benthic substrata favourable for settlement and metamorphosis.

\section{CCL settlement cues and larval swimming}

Our study also showed that the pattern of swimming activity described above was not evident when settlement cues were present. The effect of mussels and barnacles on swimming and triggering settlement confirms the observations of previous studies (DiSalvo \& Carriker 1994, Manríquez et al. 2004, 2009). However, the effect of depth on larval displacement in Conc- holepas concholepas should be investigated further. Therefore, if CCL behave in nature as in the laboratory, we suggest that larval behaviour might differ depending on the presence or absence of settlement cues and the water depth.

\section{CCL mucous thread and water movement}

Our observations in the upward current experiment (Expt 3) allowed us to observe the production of mucous threads by CCL and their attachment to fragments of floating alga. This ability of CCL to produce a mucous thread and entrap air bubbles confirms the observations of previous studies with CCL (DiSalvo 1988). Similar records have been described for bivalves and other gastropods regarding production of mucous thread and upward transport by turbulence and determining the secondary drifting of an infaunal bivalve (Verwey 1966, Lane et al. 1985, Beukema \& de Vlas 1989, Martel \& Chia 1991a,b, Nozais et al. 1997, Wang \& Xu 1997). Therefore, it appears that the use of a mucous thread is a common phenomenon in veliger larvae and may be important for onshore larval transport. In CCL this ability seems to be important up to the point where settlement-inducing cues trigger their persistence near the bottom. This information may be useful in the design of collecting devices, which could contain natural settlement cues, such as nearshore floating cages that would collect CCL travelling in the water column or cages deployed in the subtidal or low rocky intertidal to collect CCL which reach the benthic environment. This highlights the role of behavioural traits during the ontogenetic nicheshift from planktonic to benthic existence in marine invertebrates with complex life cycles, such as Concholepas concholepas. Finally, we suggest that these traits should be incorporated into the methods used to capture CCL whether for research purposes, i.e. in order to understand their recruitment variability, or for the initiation of aquaculture or natural restocking.

Note that while this manuscript was being edited for resubmission, ca. $2800 \mathrm{CCL}$ were collected during 3 days in late September of 2010 at 2 locations in Antofagasta Bay associated with nearshore foam slicks. Since our surface plankton net was broken, larval sampling was made using a heavy-duty deep swimming pool leaf net (800 $\mu \mathrm{m}$ mesh) connected to a plastic pole to collect the floating material on top of the water (ca. $20 \mathrm{~cm}$ ), while the boat was immobile alongside the foam slick. Since no CCL were collected in nearby water without debris and foam, this evidence reinforces our conclusions regarding the importance of nearshore mechanisms of transport and larval behaviour in Concholepas concholepas. 
Acknowledgements. This paper is part of a series of contributions for the Retirement Conference of Roger N. Hughes, Bangor, March 2010. J.C.C. sincerely appreciates and acknowledges his long-lasting friendship with Roger and his wife, Helen, which began during his PhD studies in Bangor, University of Wales. P.H.M. thanks Roger for his continuous support and advice as his $\mathrm{PhD}$ advisor in Bangor. We are most grateful to our friends A. Rosson, S. Vera, C. Romero, I. Albornoz, F. Orellana and M.E. Jara for logistical support. We thank the fishermen of Caleta El Quisco for help in collecting CCL, especially R. Veas, J. Marchant and the late M. Ramírez and F. Ceballos. This research was supported by Fondecyt grant nos. 3503-89 and 1930684, FONDAP-Fondecyt 15010001 CASEB (J.C.C.), and Fondecyt grant nos. 3020035, 1050841 and 1080023 (P.H.M.). We are sincerely grateful to the Estación Costera de Investigaciones Marinas (ECIM) for allowing us full use of their laboratory facilites to conduct most of the experiments in Las Cruces. We also thank M. Clarke and M. Oliva for providing laboratory facilities in the Universidad de Antofagasta. We sincerely thank 3 anonymous reviewers for their comments which substantially improved the manuscript, and also acknowledge the support of the Dirección de Investigación y Desarrollo (DID), Universidad Austral de Chile. This manuscript is part of an ongoing joint project between the Pontificia Universidad Católica de Chile and the Universidad Austral de Chile, financed in part by the DID, with the aim of overcoming the current difficulties in the establishment of both pilot and large-scale Concholepas concholepas aquaculture studies. Many thanks goes to M. Lee for improving the English.

\section{LITERATURE CITED}

Anderson N (1971) Intertidal activity, breeding and the floating habit of Hydrobia ulvae in Ythan estuary. J Mar Biol Assoc UK 50:423-437

Bainbridge R (1961) Migrations. In: Waterman TW (ed) The physiology of Crustacea, Vol 2. Academic Press, New York, NY, p 431-462

Bayne BL (1964) The response of the larvae of Mytilus edulis L. to light and gravity. Oikos 15:162-174

Bayne BL (1965) Growth and the delay of metamorphosis of the larvae of Mytilus edulis (L.). Ophelia 2:1-47

Beukema JJ, de Vlas J (1989) Tidal-current transport of thread-drifting postlarval juveniles of the bivalve Macoma balthica from the Wadden Sea to the North Sea. Mar Ecol Prog Ser 52:193-200

Broom DM (1979) Methods of detecting and analyzing activity rhythms. Biol Behav 1:3-18

Butman CA (1987) Larval settlement of soft-sediment invertebrates: the spatial scales of pattern explained by habitat selection and the emerging role of hydrodynamical processes. Oceanogr Mar Biol Annu Rev 25:113-165

Cañete JI, Gallardo CS, Romero M, Ambler R (2007) Planktonic drifting dispersal of early Trochita calyptraeaformis Born 1778 (Gastropoda: Calyptraidae). J Exp Mar Biol Ecol 346:1-7

Carriker MR (1990) Functional significance of the pediveliger in bivalve development. In: Morton B (ed) The bivalvia. Proc Memorial Symposium in Honour of Sir Charles Maurice Yonge. Hong Kong University Press, Hong Kong, p 267-282

Castilla JC (1988) Una revisión bibliográfica (1980-1988) sobre Concholepas concholepas (Gastropoda, Muricidae): problemas pesqueros y experiencia de repoblación. Biol Pesqu Chil 17:9-19

Castilla JC (1999) Coastal marine communities: trends and perspectives from human-exclusion experiments. Trends Ecol Evol 14:280-283

Castilla JC, Cancino J (1976) Spawning behavior and egg capsules of Concholepas concholepas (Mollusca: Gastropoda: Muricidae). Mar Biol 37:255-263

Castilla JC, Defeo O (2001) Latin American benthic shellfisheries: emphasis on co-management and experimental practices. Rev Fish Biol Fish 11:1-30

Castilla JC, Guiñez R (2000) Disjoint geographical distribution of intertidal and nearshore benthic invertebrates in the southern hemisphere. Rev Chil Hist Nat 73:585-603

Castilla JC, Lagos NA, Guinez R, Largier JL (2002) Embayments and nearshore retention of plankton: the Antofagasta Bay and other examples. In: Castilla JC, Largier JL (eds) The oceanography and ecology of the nearshore and bays in Chile. Ediciones Universidad Católica de Chile, Santiago, p 179-203

Cragg SM, Gruffydd D (1975) The swimming behaviour and the pressure responses of the veliconcha larvae of Ostrea edulis (L). In: Barnes H (ed) Proc 9th Eur Mar Biol Symp. Oban, Scotland, 1974. Aberdeen University Press, Aberdeen, p 43-57

DiSalvo LH (1988) Observations on the larval and post-metamorphic life of Concholepas concholepas (Bruguière 1789). Veliger 30:358-368

DiSalvo LH, Carriker MR (1994) Planktonic, metamorphic, and early benthic behavior of the Chilean loco Concholepas concholepas (Muricidae, Gastropoda, Mollusca). J Shellfish Res 13:57-66

Dixon PS, Irvine LM (1977) Seaweeds of the British Isles, Vol 1. Rhodophyta, Part 1. British Museum of Natural History, London

Dowse HB 2007 Statistical analysis of biological rhythm data. In: Rosato E (ed) Circadian rhythms: methods and protocols. Humana Press, Totowa, NJ, p 29-48

Dye AH (1991) Feed preferences of Nucella crassilabrum and juvenile Concholepas concholepas (Gastropoda: Muricidae) from a rocky shore in southern Chile. J Molluscan Stud 57:301-307

Edgar GJ (1987) Dispersal of faunal and floral propagules associated with drifting Macrocystis pyrifera plants. Mar Biol 95:599-610

Forward RB (1988) Diel vertical migration: zooplankton photobiology and behavior. Oceanogr Mar Biol Annu Rev 26:361-393

Fraenkel GS, Gunn DL (1961) The orientation of animals. Dover Publications, New York, NY

Fuchs HL, Mullineaux LS, Solow AR (2004) Sinking behavior of gastropod larvae (Ilyanassa obsoleta) in turbulence. Limnol Oceanogr 49:1937-1948

Fuchs HL, Neubert MG, Mullineaux LS (2007) Effects of turbulence-mediated larval behavior on larval supply and settlement in tidal currents. Limnol Oceanogr 52: 1156-1165

Gaines SD, Bertness M (1993) The dynamics of juvenile dispersal: why field ecologists must integrate. Ecology 74 : 2430-2435

Gallardo C (1973) Desarrollo intracapsular del Concholepas concholepas (Bruguière) (Gastropoda, Muricidae). Mus Nac Hist Nat Publ Ocas (Santiago) 16:3-16

Hidu H, Haskin HH (1978) Swimming speeds of oyster larvae Crassostrea virginica in different salinities and temperatures. Estuaries 1:252-255

> Highsmith RC (1985) Floating and algal rafting as potential dispersal mechanisms in brooding invertebrates. Mar Ecol Prog Ser 25:169-179

Kingsford MJ (1990) Linear oceanographic features: a focus 
for research on recruitment processes. Aust J Ecol 15: 391-401

Lancellotti DA, Trucco RG (1993) Distribution patterns and coexistence of six species of the amphipod genus Hyale. Mar Ecol Prog Ser 93:131-141

Lane DJW, Beaumont AR, Hunter JR (1985) Byssus drifting threads of the young post-larval mussel Mytilus edulis. Mar Biol 84:301-308

Largier JL (2002) Linking oceanography and nearshore ecology: perspectives and challenges. In: Castilla JC, Largier JL (eds) The oceanography and ecology of the nearshore and bays in Chile. Ediciones Universidad Católica de Chile, Santiago, p 207-239

> LeFèvre J, Bourget E (1992) Hydrodynamics and behaviour: transport processes in marine invertebrate larvae. Trends Ecol Evol 7:288-289

Levinton JS (1979) The effect of density upon deposit-feeding populations: movement, feeding and floating of Hydrobia ventrosa Montagu (Gastropoda: Prosobranchia). Oecologia 43:27-39

Manríquez PH, Castilla JC (2001) Significance of marine protected areas in central Chile as seeding grounds for the gastropod Concholepas concholepas. Mar Ecol Prog Ser 215:201-211

- Manríquez PH, Navarrete SA, Rosson A, Castilla JC (2004) Settlement of the gastropod Concholepas concholepas on shells of conspecific adults. J Mar Biol Assoc UK 84: 651-658

Manríquez PH, Delgado AP, Jara ME, Castilla JC (2008). Field and laboratory experiments with early ontogenetic stages of Concholepas concholepas. Aquaculture 279: 99-107

Manríquez PH, Lagos NA, Jara ME, Castilla JC (2009) Adaptive shell color plasticity during the early ontogeny of an intertidal keystone predator. Proc Natl Acad Sci USA 106: 16298-16303

Martel A (1988) Drifting as an important dispersal and recruitment mechanism in small intertidal invertebrates. Am Zool 28:139A

Martel A, Chia FS (1991a) Drifting and dispersal of small bivalves and gastropods with direct development. J Exp Mar Biol Ecol 150:131-147

Martel A, Chia FS (1991b) Foot-raising behaviour and active participation during the initial phase of post-metamorphic drifting in the gastropod Lacuna spp. Mar Ecol Prog Ser 72: $247-254$

Martínez P, Navarrete SA (2002) Temporal and spatial variation in settlement of the gastropod Concholepas concholepas in natural and artificial substrata. J Mar Biol Assoc UK 82:257-264

Mendez MA, Cancino JM (1990) Preferencias alimentarias de ejemplares postmetamórficos y juveniles de Concholepas concholepas (Bruguière, 1789). Rev Biol Mar Valparaíso 25:109-120

> Miron G, Boudreau B, Bourget E (1995) Use of larval supply in benthic ecology: testing correlations between larval supply and larval settlement. Mar Ecol Prog Ser 124:301-305

- Molinet C, Arévalo A, González M, Moreno CA, Arata J, Niklitschek E (2005) Patterns of larval distribution and settlement of Concholepas concholepas (Bruguiere, 1789) (Gastropoda, Muricidae) in fjords and channels of southern Chile. Rev Chil Hist Nat 78:409-423

Molinet C, Valle-Levinson A, Moreno CA, Cáceres M, Bello M, Castillo M (2006) Effects of sill processes on the distribution of epineustonic competent larvae in a stratified system of Southern Chile. Mar Ecol Prog Ser 324:95-104

Molinet C, Niklitschek E, Moreno CA, Arevalo A (2008) Ver- tical distribution of early and competent larvae of Concholepas concholepas in two systems of Chilean inland seas. Mar Biol 153:779-787

> Moreno CA, Ascencio G, Duarte WE, Marín V (1998) Settlement of the muricid Concholepas concholepas and its relationship with El Niño and coastal upwellings in southern Chile. Mar Ecol Prog Ser 167:171-175

> Narváez D, Leiva G, Poulin E, Hernández E, Navarrete S, Castilla JC (2004) Spatial and temporal variability of the oceanographic conditions in the inner shelf of central Chile. Contin Shelf Res 24:279-292

Naylor E (1988) Clock-controlled behaviour in intertidal animals. In: Chelazzi G, Vannini M (eds) Behavioural adaptation to intertidal life, NATO Ser Vol 151. Plenum Press, New York, NY, p 125-136

> Nozais C, Duchene J, Bhaud M (1997) Control of position in the water column by the larvae of Poecilochaetus serpens (Polychaeta): the importance of mucus secretion. J Exp Mar Biol Ecol 210:91-106

> Palmer AR, Strathmann RR (1981) Scale of dispersal in varying environments and its implications for life histories of marine invertebrates. Oecologia 48:308-318

> Pechenik JA (1986) Field evidence for delayed metamorphosis of larval gastropods: Crepidula fornicata, C. plana, and Bittium alternatum. J Exp Mar Biol Ecol 97:313-319

Pechenik JA (2000) On the benefits of being a larva -or not. In: Whitfield M, Matthews J, Reynolds C (eds) Aquatic life cycle strategies: survival in a variable environment. Occ Publ Mar Biol Assoc UK 6:97-104

Peña G, Hueoe P, Lepez I, Aracena O, Olivares O, Santos C (1994) Registro de larvas de Concholepas concholepas en el plancton costero de Bahía San Vicente y Coliumo, VIII Región. Bol Soc Bio Concepción 65:81-87

Pineda J (1991) Predictable upwelling and the shoreward transport of planktonic larvae by internal tidal bores. Science 253:548-551

Pineda J (1994) Spatial and temporal patterns in barnacle settlement rate along a southern California rocky shore. Mar Ecol Prog Ser 107:125-138

Poulin E, Palma AT, Leiva G, Hernández E, Martinez P, Navarrete SA, Castilla JC (2002a) Temporal and spatial variation in the distribution of epineustonic competent larvae of Concholepas concholepas (Gastropoda: Muricidae) in the central coast of Chile. Mar Ecol Prog Ser 229:95-104

> Poulin E, Palma AT, Leiva G, Narváez DA, Navarrete SA, Castilla JC (2002b) Avoiding offshore transport of competent larvae during upwelling events: the case of the gastropod Concholepas concholepas in central Chile. Limnol Oceanogr 47:1248-1255

Scheltema RS (1986) On dispersal and planktonic larvae of benthic invertebrates: an eclectic overview and summary of problems. Bull Mar Sci 39:290-322

Shanks AL (1983) Surface slicks associated with tidally forced internal waves may transport pelagic larvae of benthic invertebrates and fishes shoreward. Mar Ecol Prog Ser 13: $311-315$

Shanks AL (1985) Behavioral basis of internal-wave-induced shoreward transport of megalopae of the crab Pachygrapsus crassipes. Mar Ecol Prog Ser 24:289-295

Shanks AL (1986) Tidal periodicity in the daily settlement of intertidal barnacle larvae and hypothesized mechanism for cross-shelf transportation of cyprids. Biol Bull (Woods Hole) 170:429-440

- Shanks AL, Largier J, Brink L (2000) Demonstration of the onshore transport of larval invertebrates by the shoreward movement of an upwelling front. Limnol Oceanogr 45: $230-236$ 
Strathmann RR (1974) The spread of sibling larvae of sedentary marine invertebrates. Am Nat 108:29-44

Thiel M, Gutow L (2005a) The ecology of rafting in the marine environment. I. The floating substrata. Oceanogr Mar Biol Annu Rev 43:181-264

Thiel M, Gutow L (2005b) The ecology of rafting in the marine environment. II. The rafting organisms and community. Oceanogr Mar Biol Annu Rev 43:279-418

Thorson G (1950) Reproductive and larval ecology of marine bottom invertebrates. Biol Rev Camb Philos Soc 25:1-15

- Van der Merwe D, McLachlan A (1987) Significance of freefloating macrophytes in the ecology of a sandy beach surf zone. Mar Ecol Prog Ser 38:53-63

Vandendriessche S, Vincx M, Degraer S (2007) Floating seaweed and the influences of temperature, grazing and clump size on raft longevity - a microcosm study. J Exp Mar Biol Ecol 343:64-73

> Vargas CA, Narváez DA, Piñones A, Venegas RM, Navarrete SA (2004) Internal tidal bore warm fronts and settlement of invertebrates in central Chile. Estuar Coast Shelf Sci 61: 603-612

Vargas CA, Manríquez PH, Navarrete SA (2006a) Feeding by larvae of intertidal invertebrates: assessing their position in pelagic food webs. Ecology 87:444-457

Submitted: June 7, 2010; Accepted: March 25, 2011
Vargas C, Narváez DA, Piñones A, Navarrete SA, Lagos NA (2006b) River plume dynamic influences transport of barnacle larvae in the inner shelf off central Chile. J Mar Biol Assoc UK 86:1057-1065

Verwey J (1966) The role of some external factors in the vertical migration of marine animals. Neth J Sea Res 3: 245-266

Wang WX, Xu ZZ (1997) Larval swimming and postlarval drifting behavior in the infaunal bivalve Sinonovacula constricta. Mar Ecol Prog Ser 148:71-81

Young CM (1995) Behavior and locomotion during the dispersal phase of larval life. In: McEdward LR (ed) Ecology of marine invertebrates. CRC Press, Boca Raton, FL, p 249-277

Young CM, Chia FS (1987) Abundance and distribution of pelagic larvae as influenced by predation, behavior, and hydrographic forces. In: Giese AC, Pearse JS (eds) Reproduction of marine invertebrates, Vol IX. Blackwell Scientific Publishers, Palo Alto, CA, p 383-463

> Young TP, Petersen DA, Clary JJ (2005) The ecology of restoration: historical links, emerging issues and unexplored realms. Ecol Lett 8:662-673

Zar JH (1999) Biostatistical analysis. Prentice-Hall, Upper Saddle River, NJ

Proofs received from author(s): May 10, 2011 